\title{
Przestrzenne zróżnicowanie wielkości ruchu turystycznego w Grecji
}

\section{WPROWADZENIE}

Grecja od lat należy do krajów, w których turystyka ma bardzo duże znaczenie, decydują o tym wyjątkowe walory przyrodnicze i kulturowe. Liczba przyjazdów systematycznie rośnie i utrzymuje się na wysokim poziomie. Turystyka stała się ważnym źródłem dochodów i miejscem pracy Greków. Swoją atrakcyjność turystyczną kraj ten potrafi wykorzystać do podniesienia poziomu rozwoju gospodarczego. Na charakter ogromnego dziedzictwa kulturowego miały wpływ rozmaite kultury, przeplatające się na tym obszarze. Starożytna kultura grecka była głównym źródłem inspiracji ludzkości w trakcie jej rozwoju, a obecnie Grecja uważana jest za spadkobierczynię dawnych tradycji. Obszarem analizy jest Republika Grecka w podziale administracyjnym NUTS, przyjętym przez Unię Europejską.

Do walorów przyrodniczych odgrywających w Grecji szczególną rolę można zaliczyć rzeźbę terenu - bardzo dobrze rozwinięta linia brzegowa, głównie za sprawą licznych półwyspów, zatok oraz ogromnej liczby wysp, stanowiących $1 / 5$ powierzchni kraju. Około $80 \%$ powierzchni zajmują góry, co stanowi duży walor krajobrazowy. Szczególnie korzystną cechą środowiska dla rozwoju turystyki jest klimat. Na wyspach i wybrzeżach jest to typowy klimat śródziemnomorski, który nabiera w środkowej i wschodniej części kraju cech kontynentalnych. Na obszarach tych dominuje roślinność śródziemnomorska (cyprysy, mirty, oleandry, makia, frygana), a większe kompleksy leśne na północy kraju. W skład fauny na tych terenach wchodzi wiele gatunków rzadko spotykanych w innych częściach Europy (ptaki drapieżne, koziorożce kri-kri, agamy, kameleony, żółwie morskie, żaby nadrzewne). W Grecji istnieje dwanaście parków narodowych, dużym zainteresowaniem turystów cieszą się Park Narodowy Samarii, Park Narodowy Sunionu i najstarszy w kraju Park Narodowy Olimpu.

Walory antropogeniczne mają duże znaczenie dla kształtowania wielkości ruchu turystycznego. Szczególną rolę, obok turystyki wypoczynkowej, odgrywa turystyka kulturowa. Do najbardziej znaczących walorów pozaprzyrodniczych można zaliczyć: zabytki architektury i urbanistyki z różnych epok (antyczne, wczesnochrześcijańskie, bizantyjskie, z czasów panowania Imperium Osmańskiego), stanowiska archeologiczne (Epidauros, Delfy, Olimpia, Wergina, Mykeny, Tiryns, Dion), ośrodki kultu religijnego (Meteory, Athos), muzea archeologiczne (Muzeum Narodowe w Atenach, Salonikach, Dion, Patras, Korfu), imprezy 
kulturalne (Festiwal Ateński, festiwale teatralne w Patras i Epidauros, festiwale muzyczne w Iraklionie, Rodos, Joaninie, Festiwal Filmowy w Salonikach), Międzynarodowe Targi Salonickie, miejsca historyczne związane z ważnymi wydarzeniami (Termopile, Maraton), ośrodki tradycji i twórczości ludowej, muzykę, tradycyjne tańce (syrtaki), kuchnię grecką i zróżnicowaną sztukę ludową. Najcenniejsze i najbardziej znane miejsca zostały wpisane na Światową Listę Dziedzictwa Kultury UNESCO.

\section{ZAGOSPODAROWANIE TURYSTYCZNE I DOSTĘPNOŚĆ KOMUNIKACYJNA} JAKO CZYNNIK WARUNKUJĄCY WIELKOŚĆ RUCHU TURYSTYCZNEGO

Obok walorów turystycznych jednym z głównych czynników przyciagającym turystów, jak również zapewniającym im właściwe warunki wypoczynku, jest zagospodarowanie turystyczne. Na bazę noclegową w Grecji składają się pola namiotowe, campingi, kwatery prywatne (pokoje gościnne), pensjonaty, motele i hotele. W Grecji w 2007 r. zarejestrowanych było 9531 obiektów noclegowych, z czego 96,6\% stanowiły hotele oraz obiekty typu hotelowego. Największa ich liczba występuje na Wyspach Egejskich Południowych 1914, najmniejsza natomiast w Macedonii Zachodniej - jedynie 107. Zachodnia część kraju (Epir, Macedonia Zachodnia i Grecja Zachodnia) wyraźnie odbiegają od reszty regionów pod względem liczby obiektów noclegowych. W całym kraju w obiektach typu hotelowego i hotelach było 700933 miejsc noclegowych. W Grecji w 2007 r. czynne były 324 campingi i pola namiotowe. Zdecydowana większość położona jest nad morzem. Ich największą liczbę skupiały regiony na stałym lądzie; Macedonia Środkowa - 83 oraz Peloponez - 66 . Wszystkie campingi i pola namiotowe skupiały 90023 miejsc noclegowych, z czego prawie jedna trzecia, czyli ponad 29 tys. miejsc, znajduje się w Macedonii Środkowej (tab.1).

Tab. 1. Liczba obiektów zbiorowego zakwaterowania w Grecji w $2007 \mathrm{r}$.

\begin{tabular}{|l|l|l|l|}
\hline \multicolumn{1}{|c|}{ Region } & \multicolumn{1}{c|}{$\begin{array}{c}\text { Hotele i obiekty } \\
\text { typu hotelowego }\end{array}$} & \multicolumn{1}{c|}{$\begin{array}{c}\text { Campingi i pola } \\
\text { namiotowe }\end{array}$} & Razem \\
\hline Wyspy Egejskie Pd. & 1914 & 34 & 1948 \\
\hline Kreta & 1509 & 16 & 1525 \\
\hline Macedonia Środkowa & 1155 & 83 & 1238 \\
\hline Wyspy Jońskie & 897 & 27 & 924 \\
\hline Attyka & 685 & 10 & 695 \\
\hline Peloponez & 553 & 66 & 619 \\
\hline Tesalia & 572 & 14 & 586 \\
\hline Grecja Środkowa & 512 & 16 & 528 \\
\hline Wyspy Egejskie Pn. & 390 & 1 & 391 \\
\hline Macedonia Wsch. i Tracja & 371 & 14 & 385 \\
\hline Epir & 293 & 17 & 310 \\
\hline Grecja Zachodnia & 249 & 26 & 275 \\
\hline Macedonia Zachodnia & 107 & 0 & 107 \\
\hline GRECJA OGÓŁEM & 9207 & 324 & 9531 \\
\hline
\end{tabular}

Źródło: dane Greckiego Urzędu Statystycznego 
W Grecji przeważają hotele niższych kategorii, najwięcej, bo aż 4403 jest obiektów dwugwiazdkowych, co stanowi $48 \%$ wszystkich hoteli. Hoteli pięciogwiazdkowych w Grecji w 2007 r. było 199, z czego najwięcej w regionach, gdzie baza noclegowa jest dobrze rozwinięta i występują ekskluzywne wioski wakacyjne (Kreta - 48, Wyspy Egejskie Południowe - 37), a także w Attyce (29) i Macedonii Środkowej (22), a to ze względu na występowanie obiektów o wysokim standardzie w dwóch największych ośrodkach miejskich kraju - Atenach i Salonikach. Są to głównie hotele biznesowe i kongresowe (ryc.1).

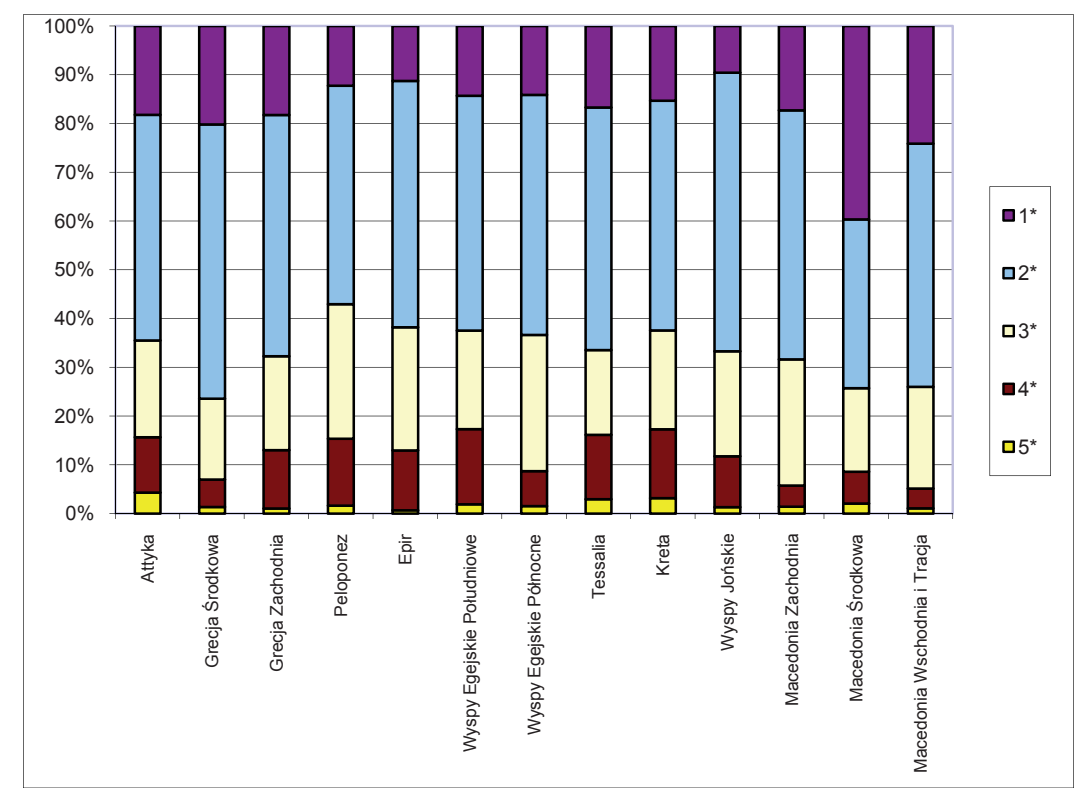

Ryc. 1. Regionalne zróżnicowanie standardu hoteli w Grecji w 2007 r.

Źródło: dane Greckiego Urzędu Statystycznego

Dla każdego z regionów administracyjnych Grecji obliczono wskaźnik gęstości bazy noclegowej (Jackowski, Warszyńska 1978). Średnia wartość tego wskaźnika wynosi 6. Mające stosunkowo niewielką powierzchnię Wyspy Egejskie Południowe oraz Wyspy Jońskie charakteryzują się największą gęstością bazy noclegowej. Jest ona również duża na Krecie i w Attyce. W skali kraju najmniej turystów na 1 miejsce noclegowe jest na wyspach (Jońskich, Egejskich i Krecie) oraz w Macedonii Środkowej. Średnia wartość wskaźnika rozwoju bazy noclegowej w Grecji wynosi 20 (tab. 2).

Tab. 2. Wskaźnik gęstości bazy noclegowej oraz wskaźnik rozwoju bazy noclegowej w Grecji w 2009 r.

\begin{tabular}{|l|c|c|}
\hline \multicolumn{1}{|c|}{ Region } & $\begin{array}{c}\text { Liczba miejsc } \\
\text { noclegowych/km }\end{array}$ & $\begin{array}{c}\text { Liczba turystów/ } \\
\text { 1 miejsce noclegowe }\end{array}$ \\
\hline Wyspy Jońskie & 39,7 & 12,2 \\
\hline Wyspy Egejskie Południowe & 32,6 & 12,4 \\
\hline Kreta & 18 & 14,9 \\
\hline Attyka & 16,9 & 55 \\
\hline
\end{tabular}




\begin{tabular}{|l|l|l|}
\hline Macedonia Środkowa & 5,8 & 18,2 \\
\hline Wyspy Egejskie Północne & 5,5 & 15,4 \\
\hline Peloponez & 3,1 & 21,7 \\
\hline Grecja Zachodnia & 2,2 & 33,6 \\
\hline Grecja Środkowa & 2,1 & 20,6 \\
\hline Tesalia & 2,1 & 28,6 \\
\hline Macedonia Wsch. i Tracja & 1,7 & 24,6 \\
\hline Epir & 1,7 & 27,6 \\
\hline Macedonia Zachodnia & 0,5 & 43,6 \\
\hline
\end{tabular}

Źródło: dane Greckiego Urzędu Statystycznego

Usługi transportowe odgrywają znaczącą rolę w ruchu turystycznym. Utrudnieniem dla rozwoju gęstej sieci komunikacyjnej w Grecji jest zróżnicowana rzeźba terenu (liczne pasma górskie i duże deniwelacje). Na sieć autostrad, które łączą główne miasta kraju, składają się: autostrada A1 z Aten do Salonik, A2 z Igoumenitsy przez Joaninę, Kavalę, aż do granicy z Turcja, autostrada A8 z Aten do Patras oraz druga na tym półwyspie z Koryntu, przez Tripoli w kierunku Kalamaty. Bardzo dobrze rozwinięta jest w Grecji sieć połączeń autobusowych. Tym środkiem transportu można dostać się niemal w każde miejsce, łącznie z niewielkimi wioskami. Prawie wszystkie połączenia obsługiwane są przez autobusy należące do prywatnej firmy KTEL (Ellingham, Dubin, Jansz, Fisher 1998).

Grecja charakteryzuje się rzadką siecią połączeń kolejowych, głównie ze względu na przeszkody orograficzne. Pociągi kursują tylko na stałym lądzie (brak kolei na wyspach). Całkowita długość linii kolejowych w 2006 r. wynosiła 2509 km (z czego $1652 \mathrm{~km}$ to tory o międzynarodowej szerokości - trasa z Aten do Salonik; resztę stanowią odcinki o innym rozstawie torów, na przykład z Volos do Kalambaki). Koleją do Grecji można dostać się z Turcji, Bułgarii i Macedonii, z Albanią nie ma połączenia.

Ze względu na mieszkańców licznych wysp konieczne było rozbudowanie w Grecji sieci połączeń promowych. Największymi portami na półwyspie są Pireus (zdecydowanie dominuje pod względem liczby przyjmowanych i odprawianych połączeń), Rafina, Saloniki, Patras i Kavala, popularne są kursy z włoskich portów Bari, Ankony, Wenecji i Brindisi do Igoumenitsy i Patras. Utrzymuje się też połączenia promowe z Turcją i Cyprem.

Do Grecji można dostać się przy pomocy transportu lotniczego z wielu krajów Europy i świata. Loty obsługują największe greckie linie Olympic Airlines, a także przewoźnicy z różnych krajów (Air France, British Airways, Polskie Linie Lotnicze Lot, Lufthansa, American Airlines, easyJet, Alitalia, WizzAir, Central Wings). W krajowym ruchu lotniczym biorą też udział linie Aegean Airlines i mniejsze Air Greece oraz Kriti Air. Najbardziej liczącym się przewoźnikiem są linie Olympic Airlines, które oferują wiele połączeń do kilkunastu miast europejskich, takich jak: Madryt, Genewa, Paryż, Londyn, Manchester, Bruksela, Amsterdam, Frankfurt, Düsseldorf, Stuttgart, Monachium, Mediolan, Rzym, Valetta, Berlin, Praga, Wiedeń, Belgrad, Sofia, Stambuł, Tirana, Bukareszt, Moskwa, Kijów i Odessa. Uruchomiono również loty do Azji (Bejrut, Tel Awiw, Kuwejt, Dubaj), Afryki (Johanesburg, Kair, Aleksandria) oraz do Ameryki Północnej (Toronto, Montreal, Nowy Jork) (Rusin 2007). 
Największym portem lotniczym w Grecji jest Port Lotniczy im. Eleftheriosa Venizelosa w Atenach. Posiada on połączenia z niemal wszystkimi greckimi lotniskami, łącznie z tymi z niewielkich wysp (ryc. 2).

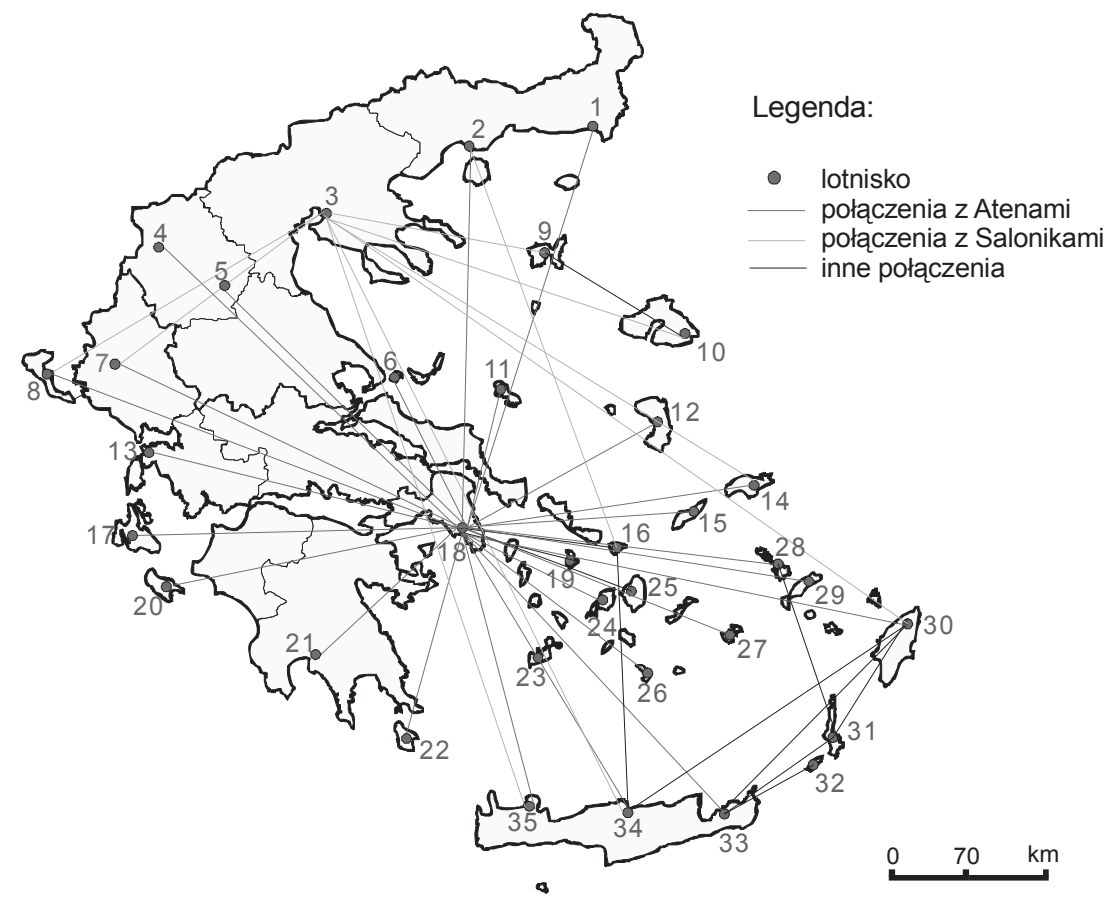

1- Aleksandroupolis, 2- Kavala, 3- Saloniki, 4- Kastoria, 5- Kozani, 6 - Skiathos, 7- Joanina, 8- Korfu, 9- Limnos, 10- Lesvos, 11- Skiros, 12- Chios, 13- Preveza, 14- Samos, 15- Ikaria, 16- Mykonos, 17- Kefalonia, 18- Ateny, 19-Syros, 20- Zakynthos, 21- Kalamata, 22- Kithira, 23- Milos, 24- Paros, 25- Naxos, 26- Santorini, 27- Astipalea, 28- Leros, 29- Kos, 30- Rodos, 31- Karpathos, 32- Kassos, 33- Sitia, 34- Iraklion, 35- Chania

Ryc. 2. Porty lotnicze i krajowe połączenia lotnicze

Źródło: opracowanie własne na podstawie danych Greckiego Urzędu Statystycznego

\section{WIELKOŚĆ I PRZESTRZENNE ZRÓŻNICOWANIE RUCHU TURYSTYCZNEGO W GRECJI}

Grecja jest jednym z chętniej odwiedzanych krajów w Europie Południowej. Liczba turystów przyjeżdżających do tego państwa systematycznie rośnie. Wielkość ruchu turystycznego w latach 1995-2007 na tle wybranych krajów europejskich przedstawiają tab. 3 i ryc. 6. Jest on niewielki w porównaniu z takimi krajami, jak Francja, Hiszpania i Włochy, które należą do europejskiej czołówki pod względem liczby przyjmowanych turystów, jednak osiagga wyższe wartości niż w przypadku Polski czy sąsiedniej Bułgarii.

Duży wzrost liczby przyjazdów do Grecji zanotowano pomiędzy rokiem 1950, gdy liczba przyjezdnych wynosiła jedynie 33,3 tys., a rokiem 1960, w którym wartość ta była ponaddziesięciokrotnie większa (389,4 tys. osób). Duży wzrost nastąpił też w dziesięcioleciach 1970-1980 oraz 1999-2000, w każdym z tych okresów zmiana wynosiła ponad 3,6 
mln turystów. Natomiast w ciągu zaledwie dwóch lat pomiędzy rokiem 2005 a 2007 liczba turystów odwiedzających Grecję wzrosła o ponad 5 mln (tab. 5).

Tab. 3. Przyjazdy do wybranych krajów europejskich

\begin{tabular}{|l|c|c|c|c|}
\hline \multirow{2}{*}{ Kraj } & \multicolumn{4}{|c|}{ Przyjazdy w mln osób } \\
\cline { 2 - 5 } & 1995 & 2000 & 2005 & 2007 \\
\hline Francja & 60 & 77,2 & 75,9 & 81,9 \\
\hline Hiszpania & 34,9 & 47,9 & 55,9 & 59,2 \\
\hline Włochy & 31,1 & 41,2 & 36,5 & 43,7 \\
\hline Grecja & 10,1 & 13,1 & 13,5 & 18,7 \\
\hline Polska & 19,2 & 17,4 & 15,2 & 15 \\
\hline Portugalia & 9,5 & 12,1 & 10,6 & 12,3 \\
\hline Chorwacja & 1,5 & 5,8 & 8,5 & 9,3 \\
\hline Bułgaria & 3,5 & 2,8 & 4,8 & 5,2 \\
\hline
\end{tabular}

Źródło: dane Instytutu Turystyki

Ważnym miernikiem służącym do lepszego przeanalizowania ruchu turystycznego w Grecji na tle innych krajów jest wielkość dochodów z turystyki. W $1950 \mathrm{r}$. wpływy z turystyki wynosiły 4,7 mln USD, w latach 70. ich wartość zaczęła znacząco wzrastać, największy skok nastąił między rokiem 1995 a 2000, natomiast w 2007 r. dochody z turystyki wynosiły 15,5 mld USD (tab. 5, ryc. 3 ).

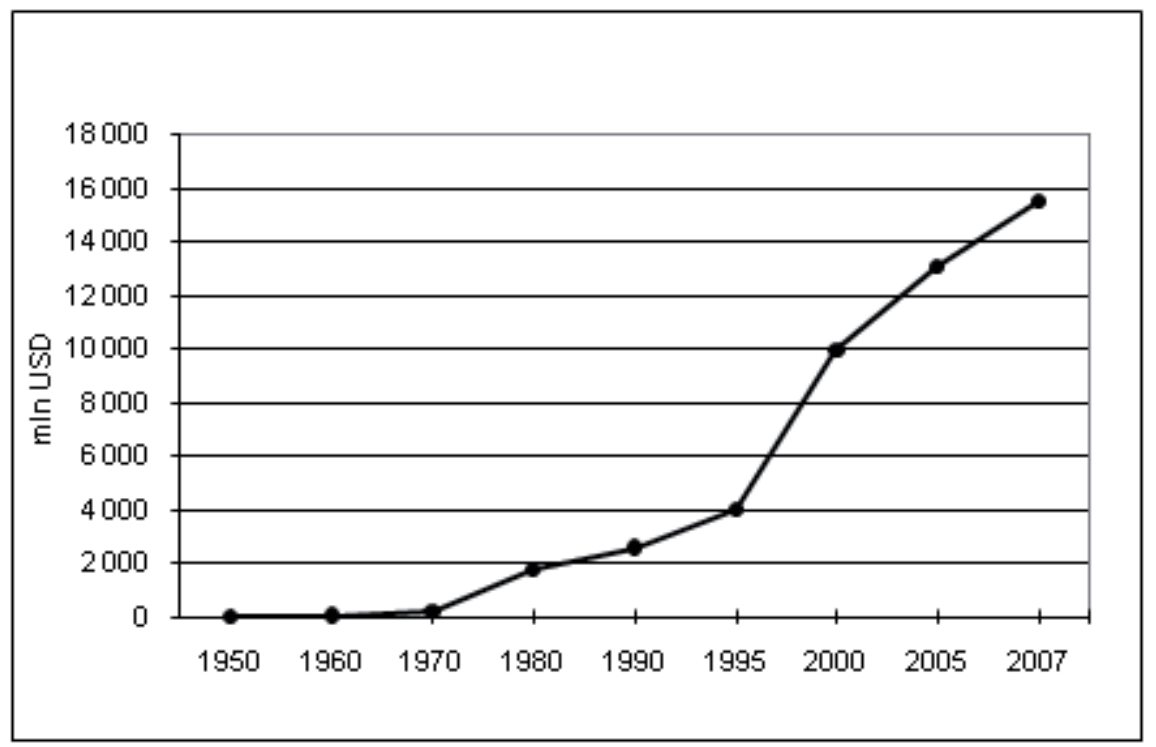

Ryc. 3. Wpływy z działalności turystycznej w Grecji w latach 1950-2007

Źródło: opracowanie własne na podstawie danych UNWTO 
W celu lepszego zobrazowania funkcji turystyki w rozwoju społeczno-gospodarczym Grecji obliczono stopień rozwoju funkcji turystycznej wybranych państw; czyli stosunek wielkości wpływów z turystyki, jakie czerpie dany kraj, do jego liczby ludności (Warszyńska, Jackowski 1978). Spośród analizowanych krajów największy stopień rozwoju funkcji turystycznej jest w Chorwacji (liczącej 4,49 mln mieszkańców) i wynosi 2627 USD/1 mieszkańca. Grecja plasuje się na drugim miejscu z wartością wskaźnika 1382 USD/1 mieszkańca. Korzystny dla Grecji wskaźnik wynika ze stosunkowo niewielkiej liczby ludności (tab. 4).

Tab. 4. Stopień rozwoju funkcji turystycznej oraz wskaźnik względnej siły przyciągania turystycznego w wybranych krajach europejskich

\begin{tabular}{|l|c|c|}
\hline \multicolumn{1}{|c|}{ Kraj } & $\begin{array}{c}\text { Suma USD / 1 } \\
\text { mieszkańca }\end{array}$ & $\begin{array}{c}\text { Suma przyjazdów } \\
\text { turystów }{ }^{\times} \text {100/liczba ludności } \\
\text { kraju docelowego }\end{array}$ \\
\hline Chorwacja & 2627 & 207 \\
\hline Grecja & 1382 & 167 \\
\hline Hiszpania & 1255 & 129 \\
\hline Portugalia & 946 & 115 \\
\hline Francja & 850 & 128 \\
\hline Włochy & 719 & 74 \\
\hline Bułgaria & 496 & 72 \\
\hline Polska & 278 & 39 \\
\hline
\end{tabular}

Źródło: opracowanie własne na podstawie danych Greckiego Urzędu Statystycznego

W turystyce istnieje zjawisko sezonowości, przejawiające się nierównomiernym natężeniem ruchu turystycznego w skali roku. Ze względu na dogodne uwarunkowania klimatyczne sezon turystyczny trwa w Grecji około pół roku. Rozpoczyna się on z początkiem maja, a gdy warunki pogodowe sprzyjają, to nawet wcześniej i trwa nieprzerwanie do ostatnich tygodni października. Zdecydowanie najwięcej turystów odwiedza Grecję w trzech miesiącach: czerwcu, lipcu i sierpniu, w każdym z nich liczba przyjazdów przekracza 2 mln (ryc. 4).

Grecja obok Włoch i Hiszpanii jest jednym z najchętniej odwiedzanych przez turystów krajem Europy Południowej. Według danych Greckiego Urzędu Statystycznego w 2007 r. do Grecji przyjechało 18754593 osób i jest to łączna liczba przyjazdów zarejestrowana przez służby celne tego kraju. Spośród krajów Unii Europejskiej najchętniej w 2007 r. przybywali do Grecji Brytyjczycy (2 618 542), Niemcy (2 264 332) oraz Włosi (1 157 081) i Bułgarzy (1 099 754). Po ponad 0,5 mln turystów przyjechało z Francji i Rumunii, z Polski nieco ponad 300 tys., natomiast najmniej chętnie przyjeżdżają do Hellady obywatele krajów nadbałtyckich (Litwy, Łotwy i Estonii) oraz Portugalii i Malty. Łączna liczba przyjazdów z państw należących do Unii Europejskiej wyniosła 12700368 (ryc. 5). 


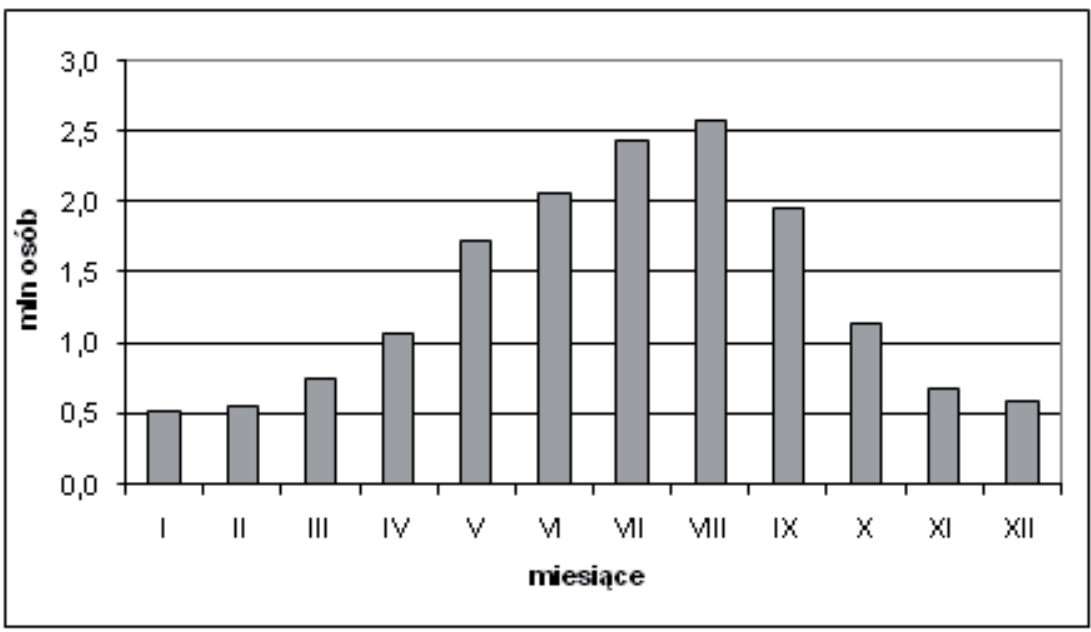

Ryc. 4. Sezonowość ruchu turystycznego w Grecji w 2007 r.

Źródło: opracowanie własne na podstawie danych Greckiego Urzędu Statystycznego

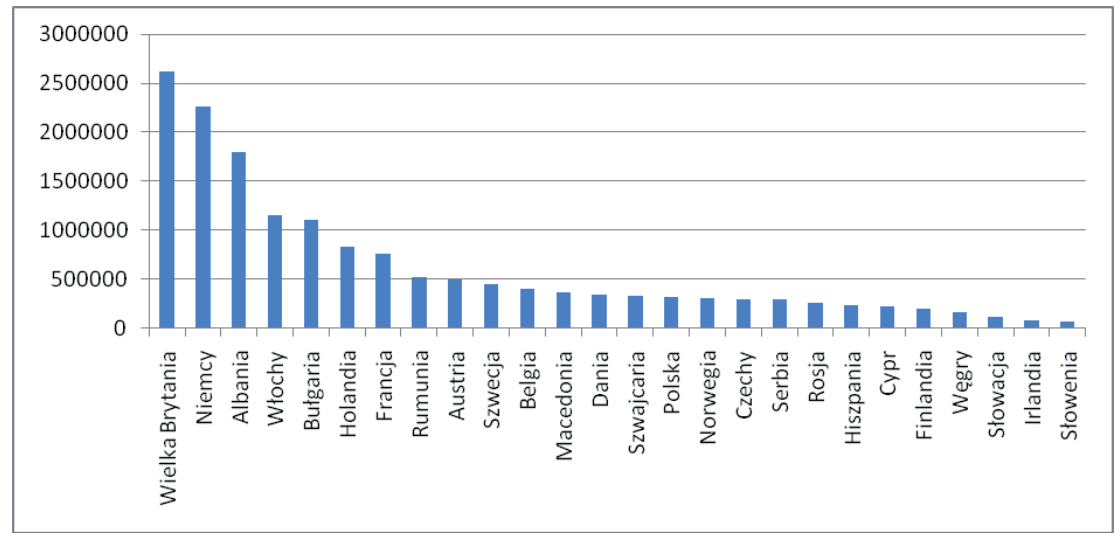

Ryc. 5. Przyjazdy obywateli państw Unii Europejskiej do Grecji w 2007 r.

Źródło: opracowanie własne na podstawie danych Greckiego Urzędu Statystycznego

Olbrzymie znaczenie w wielkości i przestrzennym zróżnicowaniu ruchu turystycznego, szczególnie turystyki przyjazdowej zagranicznej, posiada dostępność komunikacyjna. We współczesnym czasie o wyborze określonej destynacji bardzo często decyduje odległość i czas na pokonanie drogi. W przypadku Grecji turyści przybywają różnymi środkami transportu. Jak wynika z danych Greckiego Urzędu Statystycznego, dominującą formą transportu jest transport lotniczy. Samolotami do Grecji przylatuje aż 68\% wszystkich turystów. Na drugim miejscu plasuje się transport samochodowy (25\%), natomiast marginalną rolę odgrywa transport kolejowy - jedynie 1\% wszystkich przyjazdów. Najchętniej z transportu samochodowego korzystali przyjeżdżający do Grecji mieszkańcy Albanii (1 736 614), Bułgarii (1 020 424), Macedonii, Serbii i Rumunii. Z tej formy transportu skorzystało w 2007 r. 4208364 turystów (tab. 8). Turyści zmotoryzowani mają do dyspozycji 10 głównych przejść 
granicznych, w tym po trzy z Albanią, Macedonią i Turcją oraz jedno z Bułgarią. W 2007 r. do Grecji przyjechało koleją 84514 osób. O małym udziale transportu kolejowego przesadza niewielka liczba połączeń (przejścia graniczne tylko z Macedonią, Turcją i Bułgarią). Najwięcej osób przybywa koleją z krajów ościennych (tab. 8). Transport morski natomiast ma ogromne znaczenie w ruchu krajowym. Częste połączenia międzynarodowe utrzymywane są z Włochami. W 2007 r. przypłynęło do Grecji 866828 turystów, z czego najwięcej z Włoch (178 003), Niemiec (173 438), Francji i Austrii (tab. 8).

Duży udział w ogólnej liczbie przyjazdów do Grecji odgrywa transport lotniczy. Kraj ten dla przyjezdnych z Europy Północnej czy Zachodniej jest odległy, dlatego taka forma transportu wydaje się optymalna. W 2007 r. dzięki kursującym samolotom przybyło do Grecji 11084435 osób. Najwięcej przylatuje Brytyjczyków (2 521 847) oraz Niemców (2 007 842). Liczba pasażerów w ruchu lotniczym zagranicznym wyniosła 28152 059, co stanowi 68\% ogólnej liczby podróżujących samolotami (tab. 5). Dominującą rolę w liczbie odprawianych połączeń i tym samym w liczbie pasażerów odgrywa największe greckie lotnisko im. Eleftheriosa Venizelosa w Atenach.

Tab. 5. Przyjazdy obcokrajowców do Grecji według środka transportu w 2007 r.

\begin{tabular}{|l|r|r|r|r|r|}
\hline \multirow{2}{*}{$\begin{array}{l}\text { Obywatele } \\
\text { państw europejskich }\end{array}$} & Razem & $\begin{array}{c}\text { Transport } \\
\text { lotniczy }\end{array}$ & $\begin{array}{c}\text { Transport } \\
\text { kolejowy }\end{array}$ & $\begin{array}{c}\text { Transport } \\
\text { morski }\end{array}$ & $\begin{array}{c}\text { Transport } \\
\text { samochodowy }\end{array}$ \\
\cline { 2 - 6 } & 16244141 & 11084435 & 84514 & 866828 & 4208364 \\
\hline Wielka Brytania & 2618542 & 2521847 & 877 & 87261 & 8557 \\
\hline Niemcy & 2264332 & 2007842 & 937 & 173438 & 82115 \\
\hline Wlbania & 1801814 & 30795 & 3045 & 31360 & 1736614 \\
\hline Bułgaria & 1157081 & 972374 & 432 & 178003 & 6272 \\
\hline Holandia & 1099754 & 30094 & 40625 & 8611 & 1020424 \\
\hline Francja & 828185 & 782654 & 310 & 37880 & 7341 \\
\hline Rumunia & 756105 & 643490 & 212 & 104951 & 7452 \\
\hline Austria & 522033 & 81874 & 15791 & 13136 & 411232 \\
\hline Szwecja & 490320 & 446465 & 379 & 32326 & 11150 \\
\hline Belgia & 449312 & 433056 & 217 & 11894 & 4145 \\
\hline Macedonia & 396470 & 351444 & 40 & 36784 & 8202 \\
\hline Dania & 364200 & 1649 & 6844 & 99 & 355608 \\
\hline Szwajcaria & 334961 & 324220 & 335 & 9266 & 1140 \\
\hline Polska & 328290 & 312600 & 93 & 13924 & 1673 \\
\hline Norwegia & 313147 & 201032 & 1174 & 18711 & 92230 \\
\hline Czechy & 301934 & 297445 & 39 & 3807 & 643 \\
\hline Serbia & 294316 & 262653 & 1127 & 4811 & 25725 \\
\hline Rosja & 290873 & 32440 & 6104 & 1181 & 251148 \\
\hline Hiszpania & 257411 & 244196 & 375 & 7942 & 4898 \\
\hline Cypr & 237857 & 204157 & 569 & 32285 & 846 \\
\hline Finlandia & 221958 & 207161 & 349 & 12485 & 1963 \\
\hline Węry & 195125 & 187014 & 119 & 7421 & 571 \\
\hline Słowacja & 164181 & 114076 & 482 & 4766 & 44857 \\
\hline Irlandia & 108234 & 91109 & 258 & 2900 & 13967 \\
\hline Słowenia & 82106 & 78670 & 50 & 3064 & 322 \\
\hline & 63591 & 48125 & 636 & 2520 & 12310 \\
\hline
\end{tabular}




\begin{tabular}{|l|r|r|r|r|r|}
\hline Luksemburg & 30788 & 30065 & 51 & 638 & 34 \\
\hline Litwa & 25373 & 22587 & 106 & 1996 & 684 \\
\hline Łotwa & 18546 & 15414 & 176 & 2379 & 577 \\
\hline Portugalia & 11862 & 5947 & 75 & 5676 & 164 \\
\hline Malta & 7595 & 7602 & 66 & 835 & 92 \\
\hline Estonia & 6240 & 64 & 867 & 423 \\
\hline Inne kraje europejskie & 199251 & 88098 & 2557 & 13611 & 94985 \\
\hline $\begin{array}{l}\text { Obywatele } \\
\text { państw Ameryki Pn. }\end{array}$ & 530882 & 443135 & 3430 & 62162 & 22155 \\
\hline $\begin{array}{l}\text { Obywatele państw } \\
\text { azjatyckich }\end{array}$ & 529940 & 296214 & 5886 & 116788 & 111052 \\
\hline $\begin{array}{l}\text { Obywatele Australii } \\
\text { i państw Oceanii }\end{array}$ & 102973 & 79435 & 1036 & 11106 & 11396 \\
\hline $\begin{array}{l}\text { Obywatele } \\
\text { państw afrykańskich }\end{array}$ & 61130 & 56146 & 94 & 3967 & 923 \\
\hline $\begin{array}{l}\text { Obywatele } \\
\text { państw Ameryki Pd. }\end{array}$ & 48725 & 41857 & 371 & 5508 & 989 \\
\hline
\end{tabular}

Źródło: dane Greckiego Urzędu Statystycznego

W Grecji zaznacza się zróżnicowanie przestrzenne ruchu turystycznego. W roku 2007 najwięcej osób przyjechało do Attyki (2 531 977), co stanowiło ponad 22\% wszystkich przyjazdów do Grecji (są to przede wszystkim odwiedziny w Atenach, największym greckim mieście pełnym antycznych zabytków, którego nie sposób pominąć podczas zwiedzania tego kraju). Drugim obszarem cieszącym się popularnością wśród turystów jest Kreta, gdzie w 2007 r. przyjechało 2237139 osób, kolejnym są Wyspy Egejskie Południowe, odwiedzone przez 2140547 przyjezdnych. Najmniej osób w 2007 roku przyjechało do Macedonii Zachodniej (205 838), co stanowiło zaledwie 1,3\% wszystkich przyjazdów (ryc. 6). Jest to obszar o niewielkim zainteresowaniu wśród turystów, czego główną przyczyną może być fakt, iż jest jedynym regionem Grecji nie mającym dostępu do morza.

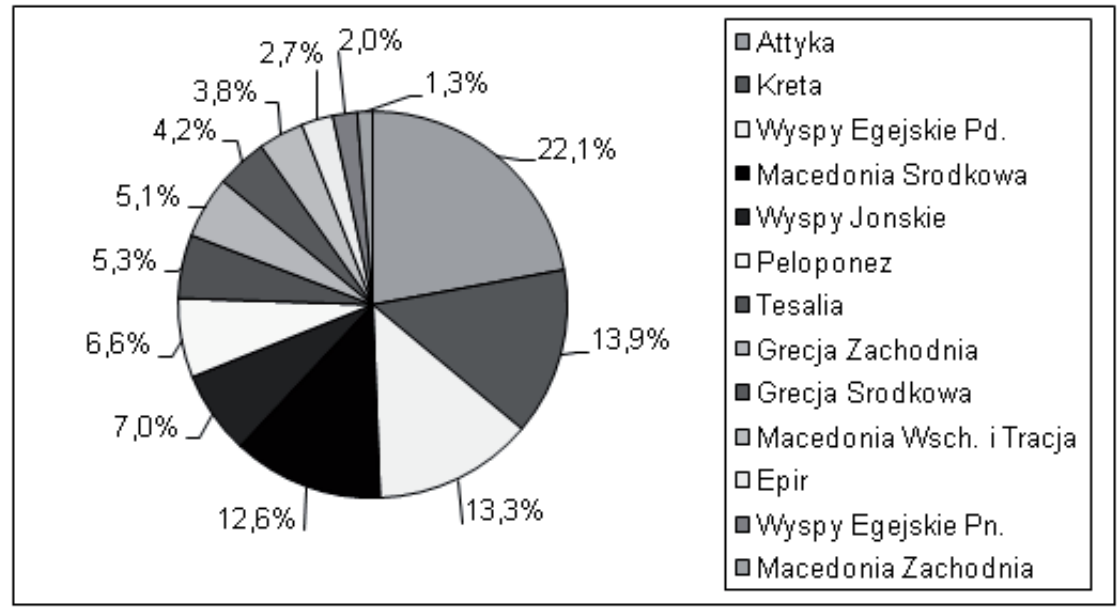

Ryc. 6. Udział poszczególnych regionów w Grecji w ogólnej liczbie przyjazdów w 2007 r.

Źródło: opracowanie własne na podstawie danych Greckiego Urzędu Statystycznego 
Tab. 6. Liczba przyjazdów do obiektów zbiorowego zakwaterowania w Grecji w 2007 r.

\begin{tabular}{|l|c|c|}
\hline \multicolumn{1}{|c|}{ Region } & $\begin{array}{c}\text { Hotele i obiekty } \\
\text { typu hotelowego }\end{array}$ & Campingi \\
\hline Attyka & 3524241 & 21861 \\
\hline Kreta & 2229183 & 7956 \\
\hline Wyspy Egejskie Pd. & 2127091 & 13456 \\
\hline Macedonia Środkowa & 1931861 & 83201 \\
\hline Wyspy Jońskie & 1089738 & 27271 \\
\hline Peloponez & 989587 & 67610 \\
\hline Tesalia & 824617 & 26171 \\
\hline Grecja Zachodnia & 797821 & 27785 \\
\hline Grecja Środkowa & 655265 & 26307 \\
\hline Macedonia Wsch. i Tracja & 590362 & 16784 \\
\hline Epir & 402717 & 23681 \\
\hline Wyspy Egejskie Pn. & 327188 & 0 \\
\hline Macedonia Zachodnia & 205838 & 0 \\
\hline GRECJA OGóŁEM & 15695509 & 342083 \\
\hline
\end{tabular}

Źródło: dane Greckiego Urzędu Statystycznego

Uwarunkowania przyrodnicze i kulturowe decydują w sposób bezpośredni o przestrzennym zróżnicowaniu ruchu turystycznego Grecji. Miarą stopnia koncentracji jest wskaźnik gęstości ruchu turystycznego, czyli stosunek liczby turystów przyjeżdżających do danego regionu do jego powierzchni (Jackowski, Warszyńska 1978). Wskaźnik osiąga najwyższą wartość dla Attyki, gdzie przypada 665 turystów na km². Wysoka wartość wskaźnika charakteryzuje też Wyspy Jońskie (384) i Wyspy Egejskie Południowe (380). Najniższą wartością wskaźnika gęstości ruchu turystycznego charakteryzują się Grecja Środkowa (34) oraz Macedonia Zachodnia-22 (tab. 7, ryc. 7). Obliczono również wskaźnik intensywności ruchu turystycznego według Schneidera, najwyższą wartość wskaźnik osiaga w rejonach wyspiarskich: Wyspy Egejskie Południowe (717), Wyspy Jońskie (521) i Kreta (372), najmniejszą zaś w Macedonii Zachodniej - 68 (tab. 7).

Tab. 7. Wskaźnik gęstości ruchu turystycznego i wskaźnik intensywności ruchu turystycznego według Schneidera w Grecji w 2007 r.

\begin{tabular}{|l|c|c|}
\hline \multicolumn{1}{|c|}{ Region } & Liczba turystów/km² & $\begin{array}{c}\text { Liczba turystów }^{\mathrm{x}} \\
\text { 100/liczba mieszkańców regionu }\end{array}$ \\
\hline Attyka & 665 & 94 \\
\hline Wyspy Jońskie & 384 & 521 \\
\hline Wyspy Egejskie Południowe & 380 & 717 \\
\hline Kreta & 193 & 372 \\
\hline Wyspy Egejskie Północne & 82 & 164 \\
\hline
\end{tabular}




\begin{tabular}{|l|c|c|}
\hline Macedonia Środkowa & 64 & 107 \\
\hline Peloponez & 57 & 167 \\
\hline Grecja Zachodnia & 57 & 111 \\
\hline Tesalia & 53 & 113 \\
\hline Epir & 44 & 121 \\
\hline Macedonia Wsch. i Tracja & 37 & 99 \\
\hline Grecja Środkowa & 34 & 112 \\
\hline Macedonia Zachodnia & 22 & 68 \\
\hline
\end{tabular}

Źródło: opracowanie własne na podstawie danych Greckiego Urzędu Statystycznego

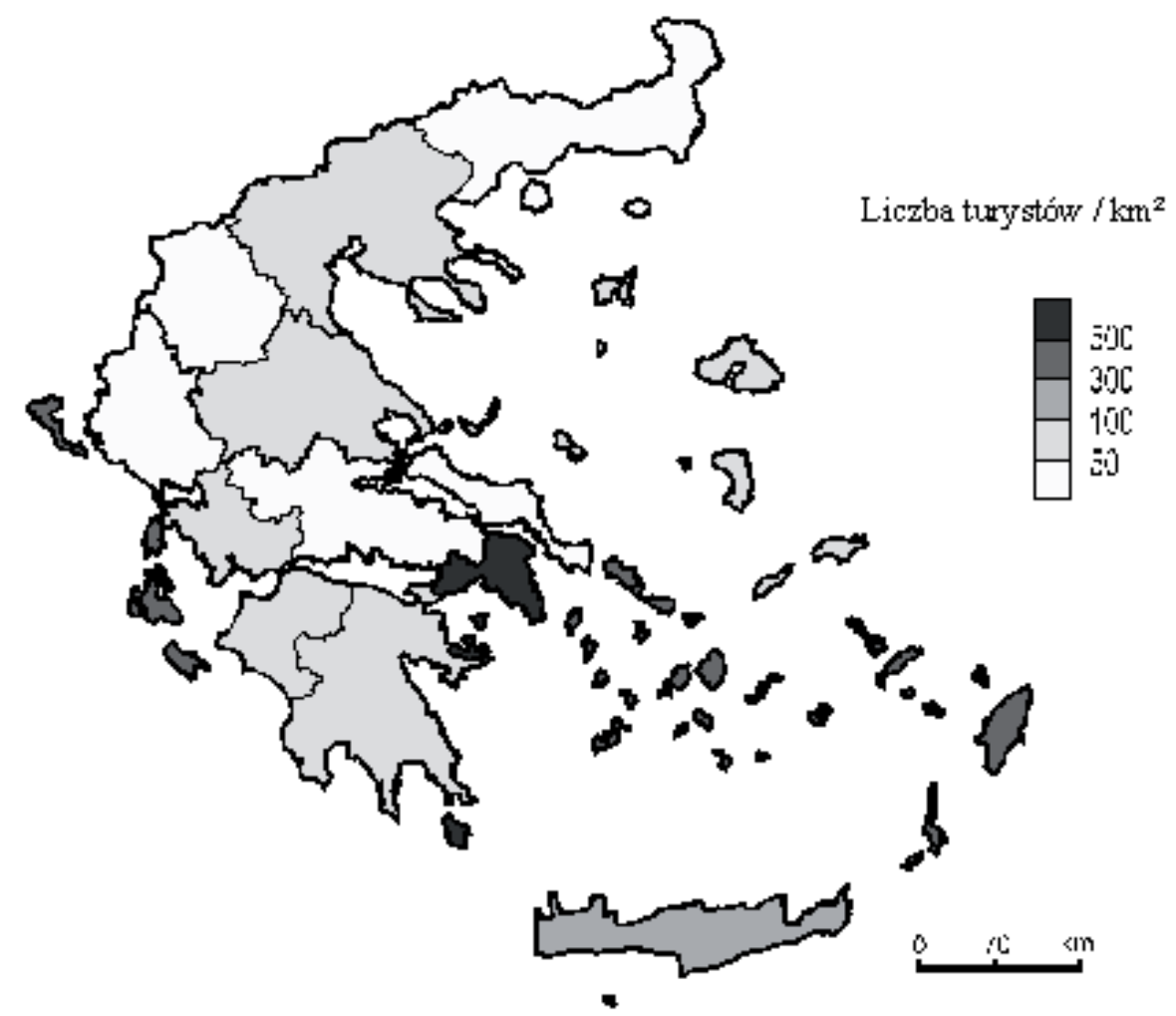

Ryc. 7. Przestrzenne zróżnicowanie wielkości wskaźnika gęstości ruchu turystycznego w Grecji w 2007 r.

Źródło: opracowanie własne na podstawie danych Greckiego Urzędu Statystycznego

\section{Podsumowanie}

Grecja jest krajem, który dzięki swoim walorom jest w stanie zaspokoić zróżnicowane oczekiwania przyjezdnych. Ciepły, umiarkowany klimat, tysiące kilometrów malowni- 
czych wybrzeży, urozmaicona rzeźba terenu, osobliwości fauny i flory są dużym atutem dla amatorów wypoczynku. Jednak do Hellady turystów przyciaga przede wszystkim ogromne dziedzictwo kulturowe. Grecja jako kolebka cywilizacji jest obszarem dużej koncentracji cennych zabytków z różnych epok.

Kraj należy do chętnie odwiedzanych przez turystów, a liczba przyjezdnych ciągle wzrasta. Według analizowanych $\mathrm{w}$ opracowaniu danych statystycznych, liczba przyjazdów w 2007 r. wynosiła 18754593 osoby, z czego ponad 92\% stanowili Europejczycy. Najchętniej do Grecji przyjeżdżają obywatele Wielkiej Brytanii, Niemiec, Włoch, Holandii, Francji oraz krajów ościennych - Bułgarii, Albanii i Macedonii. Najczęściej wybieranym przez turystów środkiem transportu jest samolot (68\%), natomiast w ruchu samochodowym uczestniczą przede wszystkim przyjezdni z krajów sąsiednich.

W porównaniu z innymi krajami europejskimi wybranymi do analizy, Grecja osiaga wysoką wartość wskaźnika stopnia rozwoju funkcji turystycznej oraz wskaźnika względnej siły przyciągania turystycznego. Na tle innych krajów Europy Południowej osiaga wysokie dochody z działalności turystycznej oraz cieszy się większym zainteresowaniem przyjezdnych.

W Grecji zaznacza się zróżnicowanie przestrzenne ruchu turystycznego. Największym zainteresowaniem przyjezdnych cieszy się Attyka oraz Wyspy Egejskie Południowe, Jońskie i Kreta. Greckie wyspy posiadają liczne walory: łagodny klimat, urozmaiconą rzeźbę oraz bogatą i zróżnicowaną kulturę. Obecnie mają charakter miejsc typowo wypoczynkowych, otwierających się na rzesze turystów poprzez szybką poprawę infrastruktury turystycznej. Największa gęstość ruchu turystycznego charakteryzuje regiony wyspiarskie, najmniejsza Epir i Macedonię Zachodnią. Wskaźnik intensywności ruchu turystycznego osiąga najwyższą wartość w przypadku Wysp Egejskich Południowych, najniższą dla Macedonii Zachodniej.

Grecja jest zatem krajem, w którym zaznacza się duży wpływ warunków naturalnych i dziedzictwa kulturowego na rozwój ruchu turystycznego w poszczególnych regionach. Fakt ten przekłada się automatycznie na poziom rozwoju zagospodarowania turystycznego wybranych obszarów.

\section{Literatura}

Ellingham M., Dubin M., Jansz N., Fisher J., 1998, Grecja-pótwysep, Wydawnictwo Pascal, BielskoBiała.

Flis J., 1966, Pótwysep Bałkański, [w:] Geografia fizyczna świata, red. Z. Czeppe, J. Flis, R. Mochancki, Wydawnictwo Naukowe PWN, Warszawa.

Gaworecki W., 2007, Turystyka, Polskie Wydawnictwo Ekonomiczne, Warszawa.

Grecja - mapa samochodowa, 2005, Wydawnictwo Copernicus, Wiedeń.

Kowalczyk A., 2001, Geografia turyzmu, Wydawnictwo Naukowe PWN, Warszawa.

Rusin W., 2007, Grecja, Wydawnictwo Pascal, Bielsko-Biała.

Warszyńska J., Jackowski A., 1978, Podstawy geografii turyzmu, PWN, Warszawa. 


\section{Spatial differentiation of tourism intensity in Greece}

Owing to its features, Greece is a country that can meet a whole range of tourist expectations. The country is a popular destination - the number of tourists is constantly increasing; in 2007 the number amounted to $18,754,593$ visitors, over $92 \%$ of whom were Europeans. Greece is the most popular with the citizens of the Great Britain, Germany, Italy, Holland, France, and the neighbouring countries Bulgaria, Albania and Macedonia. However, the tourism intensity is spatially differentiated. Attica and the South Aegean region, Ionian Islands and Crete enjoy the highest popularity among tourists. The regions of islands are most intensely visited, while the lowest intensity of tourism is observed in Epirus and West Macedonia. The highest tourism intensity ratio is observed in the case of the South Aegean region, and the lowest - in West Macedonia.

dr Renata Rettinger

mgr Małgorzata Rozmus

Uniwersytet Pedagogiczny im. Komisji Edukacji Narodowej w Krakowie

Instytut Geografii

Zakład Turystyki i Badań Regionalnych

e-mail: rettinger@onet.eu 